\title{
Analisis dan Perancangan Sistem Informasi Pembelian TBS pada PT. Tri Bahtera Srikandi
}

\author{
${ }^{1}$ Megawari, ${ }^{2}$ Djoni, ${ }^{3}$ Culita \\ Universitas Mikroskil \\ Medan, Indonesia \\ 1․megawari99@email.com, ${ }^{2}$ djoni@mikroskil.ac.id, ${ }^{3}$ culita@mikroskil.ac.id
}

*Corresponding Author

$\begin{array}{ll}\text { Diajukan } & : 24 / 11 / 2021 \\ \text { Diterima } & : 25 / 11 / 2021 \\ \text { Dipublikasi } & : 30 / 11 / 2021\end{array}$

\section{ABSTRAK}

Perkembangan teknologi informasi yang pesat mendorong pelaku usaha untuk mengadopsinya sebagai bagian dalam aktivitas operasionalnya. Salah satunya adalah dengan menerapkan sistem informasi dalam mendukung operasional bisnis dan menghasilkan informasi untuk mendukung pengambilan keputusan. PT. Tri Bahtera Srikandi merupakan salah satu perusahaan di Tandikek yang bergerak dibidang perkebunan dan industri pengolahan tandan buah segar (TBS) menjadi Crude Palm Oil (CPO) yang memiliki pabrik di Desa Tandikek, Kecamatan Ranto Baek, Kabupaten Mandailing Natal. Saat ini, proses pembelian pada PT. Tri Bahtera Srikandi masih dilakukan secara manual dan belum memiliki sistem yang terkomputerisasi. Aktivitas pembelian mulai dari pembuatan kontrak, pembelian dan penerimaan barang masih menggunakan metode konvensional. Hal ini menimbulkan banyak masalah seperti kesalahan pencatatan, data yang duplikat ataupun tidak valid serta kesulitan mengetahui informasi terkait pembelian, penerimaan dan pembayaran. Oleh karena itu, penelitian ini bertujuan menganalisis dan merancang sistem informasi pembelian dan pengolahan data Tandan Buah Segar (TBS) pada PT. Tri Bahtera Srikandi. Metodologi yang digunakan dalam penelitian ini adalah System Development Life Cycle (SDLC). Sistem informasi ini dirancang dengan menggunakan Microsoft Visual Studio 2012 dan Microsoft SQL 2012. Untuk rancangan proses dan alur data dikembangkan dengan menggunakan Data Flow Diagram (DFD). Dari hasil penelitian diperolah rancangan sistem usulan yang dapat memberikan kemudahan dalam mengetahui delivery order dari supplier, menyesuaikan penomoran delivery order dengan kontrak, pengelolaan pembelian, menyajikan laporan yang dibutuhkan dan mempermudah dalam melihat pembayaran. Diharapkan hasil dari analisis dan perancangan sistem informasi ini dapat dijadikan referensi untuk pengembangan sistem informasi pembelian Tandan Buah Segar (TBS) bagi PT. Tri Bahtera Srikandi.

Kata Kunci: Analisis dan Perancangan, Pembelian, TBS, SDLC, Sistem Informasi

\section{PENDAHULUAN}

Perkembangan teknologi informasi yang pesat mendorong pelaku usaha untuk mengadopsinya sebagai bagian dalam aktivitas operasionalnya. Teknologi merupakan sebuah alat yang mampu memudahkan manusia dalam kehidupan sehari-hari sehingga banyak perusahaan yang menerapkan teknologi untuk meningkatkan kinerja perusahaan dan berharap agar dapat mampu menghadapi persaingan yang ketat saat ini. Salah satunya adalah dengan menerapkan sistem informasi dalam mendukung operasional bisnis dan menghasilkan informasi untuk mendukung pengambilan keputusan.

Kelapa sawit merupakan tumbuhan tropis yang termasuk tanaman tahunan dan digunakan untuk keperluan industri, industri minyak olahan dan industri bahan lainnya. PT. Tri Bahtera Srikandi merupakan salah satu perusahaan di Tandikek yang bergerak dibidang perkebunan dan industri pengolahan tandan buah segar (TBS) menjadi Crude Palm Oil (CPO) yang memiliki 
pabrik di Desa Tandikek, Kecamatan Ranto Baek, Kabupaten Mandailing Natal dan memiliki kantor pusat Jl. Setiabudi komplek setiabudi kel. Tanjung sari, Kec Medan Selayang. Bahan baku TBS pada perusahaan diperoleh dari kebun inti milik perusahaan dan juga berasal dari pihak ketiga yaitu plasma dan mitra. Pihak ketiga plasma adalah kebun milik petani namun perusahaan yang mengurus, sedangkan pihak mitra adalah kebun milik petani yang diurus oleh petani sendiri. Truk pengangkutan pada pihak ketiga mitra menggunakan truk milik supplier sendiri, namun untuk plasma dapat menggunakan truk perusahaan maupun truk supplier. Dalam proses pembelian TBS kepada pihak plasma perusahaan memiliki kontrak dan Delivery Order (D.O), sedangkan untuk mitra dan inti hanya memiliki D.O.

Saat ini, proses pembelian pada PT. Tri Bahtera Srikandi masih dilakukan secara manual dan belum memiliki sistem yang terkomputerisasi. Aktivitas pembelian mulai dari pembuatan kontrak, delivery order (DO), pembelian TBS dan penerimaan barang masih menggunakan metode konvensional yakni melalui Microsoft Word dan Microsoft excel ataupun dicatat dibuku. Hal ini menyebabkan masalah seperti penomoran kontrak dan delivery order (DO) yang tidak sama sehingga kesulitan dalam mengetahui informasi terkini mengenai delivery order (DO) dan kesesuaiannya dengan kontrak dari setiap supplier.

Untuk proses penerimaan, setiap pembelian TBS akan diterima di tempat penerimaan TBS yaitu pabrik kelapa sawit (PKS). Ketika truk pengangkutan sampai di PKS, truk akan ditimbang di jembatan timbangan dan karyawan timbangan akan mencatat dan memberikan bukti penerimaan pembelian kepada supplier. Selanjutnya akan dilakukan pencatatan duplikasi yakni diinput kembali di Microsoft excel sehingga hal tersebut tidak efisien karena melakukan pekerjaan yang sama.

Pada proses pembayaran, karyawan kesulitan dalam mencocokan antara penerimaan pembelian dengan faktur pembelian yang telah diberikan oleh supplier. Hal ini dikarenakan bukti penerimaan pembelian mitra dan plasma yang sering tidak sesuai dengan data dari setiap supplier; karena tidak adanya validasi dan juga duplikasi pencatatan. Sehingga terkadang terjadi kesalahan dalam melakukan pembayaran dan nominal pembayaran yang tidak sesuai. Dari sisi pembuatan laporan, membutuhkan banyak waktu dalam membuat laporan dikarenakan masih harus diolah secara manual. Dan juga terkadang terjadi salah pengetikan nominal pada laporan yang dikirimkan, sehingga perlu dikoreksi dan dikirimkan kembali. Hal ini tentunya memperlambat pengolahan data dan informasi yang seharusnya segera dilaporkan ke pimpinan perusahaan. Oleh karena itu PT. Tri Bahtera Srikandi membutuhkan sistem yang dapat memberikan kemudahan dalam mengetahui delivery order dari supplier, menyesuaikan penomoran delivery order dengan kontrak, mengelola pembelian, menyajikan laporan yang dibutuhkan dan mempermudah dalam melihat informasi terkait pembayaran.

\section{STUDI LITERATUR Sistem Informasi}

Menurut (Jr., Prince, \& Cegielski, 2014) Sistem informasi adalah proses mengumpulkan, memproses, menyimpan, menganalisis, dan menyebarkan informasi untuk tujuan tertentu. Tujuan sistem informasi dapat didefinisikan sebagai untuk mendapatkan informasi yang tepat kepada orang yang tepat, pada waktu yang tepat, dalam jumlah yang tepat, dan dalam format yang tepat. Sedangkan menurut (O'Brien, 2017) Sistem informasi adalah kombinasi dari orang-orang, perangkat keras, perangkat lunak, jaringan komunikasi, sumber daya data dan kebijakan serta prosedur dalam menyimpan, mendapatkan kembali, mengubah dan menyebarkan informasi dalam suatu organisasi. Orang-orang bergantung pada sistem informasi modern untuk berkomunikasi satu sama lain dengan menggunakan berbagai macam alat (perangkat keras), instruksi dan pemprosesan informasi (perangkat lunak), saluran komunikasi (jaringan) dan penyimpanan data (sumber daya data). Walaupun sistem informasi pada saat ini biasanya berhubungan dengan komputer kita telah menggunakan sistem informasi sejak awal peradaban. Bahkan saat ini pun kita selalu menggunakan sistem informasi yang tidak ada hubungannya dengan komputer.

\section{Analisis dan Perancangan Sistem Informasi}

Analisis dan Perancangan Sistem (SAD) adalah istilah populer untuk mendefinisikan 
metodologi yang berbeda untuk mengembangkan sistem informasi berkualitas tinggi yang menggabungkan teknologi informasi, orang dan data untuk mendukung prasyarat bisnis (Srivastava, 2017). Analisis sistem terdiri dari aktivitas-aktivitas yang memungkinkan seseorang untuk memahami dan menentukan apa yang harus dicapai oleh sistem baru; dan Perancangan sistem terdiri dari aktivitas-aktivitas yang memungkinkan seseorang untuk menggambarkan secara rinci bagaimana sistem informasi akan benar-benar diimplementasikan untuk memberikan solusi yang dibutuhkan. (Satzinger, Jackson, \& Burd, 2014)

\section{Penelitian Terkait}

(Bakti, 2020) merancang aplikasi sistem informasi produksi buah kelapa sawit plasma, dalam penelitiannya tersebut menghasilkan suatu sistem terkomputerisasi yang dapat merekapitulasi produksi buah kelapa sawit, menghasilkan suatu sistem yang dengan mudah mengolah data produksi dan tidak menghabiskan banyak waktu dalam pengolahan data produksi; dengan sistem yang baru ini jika terjadi kehilangan data produksi yang sudah di cetak maka data produksi yang ada pada aplikasi sistem penerapan manajemen sistem informasi produksi buah kelapa sawit plasma dapat dengan mudah ditemukan; serta sistem yang baru dibangun ini dapat menghasilkan laporan produksi yang efektif dan akan mengurangi kesalahan-kesalahan yang seharusnya tidak terjadi.

(Novendra, Syahtriatna, \& Sadar, 2019) mengembangkan aplikasi peron sawit membantu dalam proses transaksi menjadi lebih cepat. Setelah menggunakan aplikasi, waktu yang dibutuhkan untuk melakukan proses transaksi pembelian hanya memerlukan waktu kurang dari satu menit. Proses percepatan tersebut tidak hanya terjadi pada transaksi pembelian. Tetapi juga pada transaksi penjualan dan pengeluaran. Proses selanjutnya yang paling banyak memakan waktu yaitu pembuatan laporan pembelian, penjualan dan pengeluaran. Setelah menggunakan aplikasi, waktu yang dibutuhkan untuk membuat laporan tersebut tidak lebih dari 10 menit. Dari perbandingan waktu pembuatan laporan tersebut dapat disimpulkan bahwa dengan menggunakan aplikasi memberikan dampak efisiensi serta memudahkan karyawan dalam membuat laporan secara otomatis. Aplikasi peron sawit tidak hanya dapat digunakan oleh CV. S3B saja. Namun seluruh peron sawit yang memiliki proses perghitungan yang sama dapat menggunakan aplikasi ini demi meningkatkan efisiensi, keakuratan data serta perhitungan.

(Harianja, Hendri, \& Kisbianty, 2018) merancang aplikasi pembelian dan pengelolaan TBS berbasis web yang telah dirancang menggunakan bahasa pemograman PHP dan database MySQL. Dalam penelitian tersebut dapat membantu memecah permasalahan yang terjadi sehingga memberikan kemudahan dalam pengolahan data pembelian TBS menjadi lebih cepat dan akurat. Hasil dari perancangan sistem tersebut dapat lebih membantu admin pabrik ataupun admin kantor pusat dalam penyelesaian tugas ataupun laporan dengan cepat dan efisien dan memberikan kenyamanan kepada karyawan dalam mengakses informasi yang dibutuhkan dan pengolahan data pembelian TBS

\section{System Development Life Cycle (SDLC)}

(Kenneth E. Kendall, 2014) menjabarkan bahwa System Development Life Cycle adalah suatu pendekatan beberapa tahap untuk menganalisa dan merancang sistem dimana sistem tersebut telah dikembangkan dengan sangat baik melalui penggunaan siklus kegiatan penganalisis dan pemakai secara spesifik. (Tilley \& Rosenblatt, 2017) menyatakan bahwa Analisis terstruktur adalah teknik pengembangan sistem tradisional yang telah teruji waktu dan mudah dipahami. Analisis terstruktur menggunakan serangkaian fase, yang disebut siklus hidup pengembangan sistem (SDLC), untuk merencanakan, menganalisis, merancang, mengimplementasikan, dan mendukung sistem informasi. Meskipun analisis terstruktur berkembang bertahun-tahun yang lalu, itu tetap menjadi metode pengembangan sistem yang populer. Model SDLC biasanya mencakup lima langkah, yang dijelaskan dalam bagian berikut: perencanaan sistem, analisis sistem, desain sistem, implementasi sistem, dan dukungan dan keamanan sistem.

\section{Data Flow Diagram (DFD)}

Data Flow Diagram merupakan gambaran suatu sistem yang telah ada atau sistem baru yang 
dikembangkan secara logika tanpa mempertimbangkan lingkungan fisik dimana data tersebut mengalir. Dengan adanya DFD maka pemakai sistem yang kurang memahami di bidang komputer dapat mengerti sistem yang sedang berjalan (Kenneth E. Kendall, 2014). DFD menunjukkan bagaimana data bergerak melalui sistem informasi tetapi tidak menunjukkan logika program atau langkah-langkah pemrosesan. Satu set DFD menyediakan model logis yang menunjukkan apa yang dilakukan sistem, bukan bagaimana melakukannya. (Tilley \& Rosenblatt, 2017)

\section{Pembelian}

Pembelian adalah usaha pengadaan barang atau jasa dengan tujuan yang akan digunakan sendiri untuk kepentingan proses produksi maupun untuk dijual kembali. Proses pembelian adalah sebuah struktur interaksi antara orang-orang, peralatan, metode dan pengendalian yang dirancang untuk mencapai fungsi utama yaitu Menangani rutinitas pekerjaan yang berulang-ulang dari bagian pembelian dan departemen penerimaan dan mendukung kebutuhan pengambilan keputusan dari orang-orang yang mengatur bagian pembelian dan penerimaan serta membantu dalam penyiapan laporan internal dan eksternal (Mulyadi, 2018).

\section{Siklus Pengolahan Data}

Pengolahan data terdiri dari tiga langkah utama yakni: input, proses (pengolahan) dan Output. Dalam tahapan pertama input, data awal / data input, disiapkan dalam beberapa bentuk yang sesuai untuk keperluan pengolahan. Bentuk tersebut akan bergantung pada pengolahan mesin. Pada kedua pengolahan, data input diubah, dan biasanya dikombinasikan dengan informasi yang lain untuk menghasilkan data dalam bentuk yang lebih dapat digunakan. Langkah pengolahan ini biasanya meliputi sederet operasi pengolahan dasar tertentu. Selanjutnya pada tahapan terakhir, hasil-hasil dari pengolahan sebelumnya dikumpulkan. Bentuk data Output tergantung pada penggunaan data tersebut unutk pengolahan selanjutnya. (YS, 2011)

\section{METODE}

Metodologi yang digunakan dalam tugas akhir ini mengacu pada System Development Life Cycle (SDLC) yang terdiri dari tahapan sebagai berikut:

1. Mengidentifikasi masalah, peluang dan tujuan

Proses-proses yang dikerjakan pada tahapan ini adalah:

a. Merangkum masalah perusahaan dengan menggunakan diagram fishbone dalam sistem pembelian dan pengolahan data TBS yang sedang berjalan pada PT. Tri Bahtera Srikandi.

b. Merangkum hal-hal yang diinginkan perusahaan supaya permasalahan dalam sistem pembelian dan pengolahan data TBS bisa diatasi dan tujuan perusahaan tercapai.

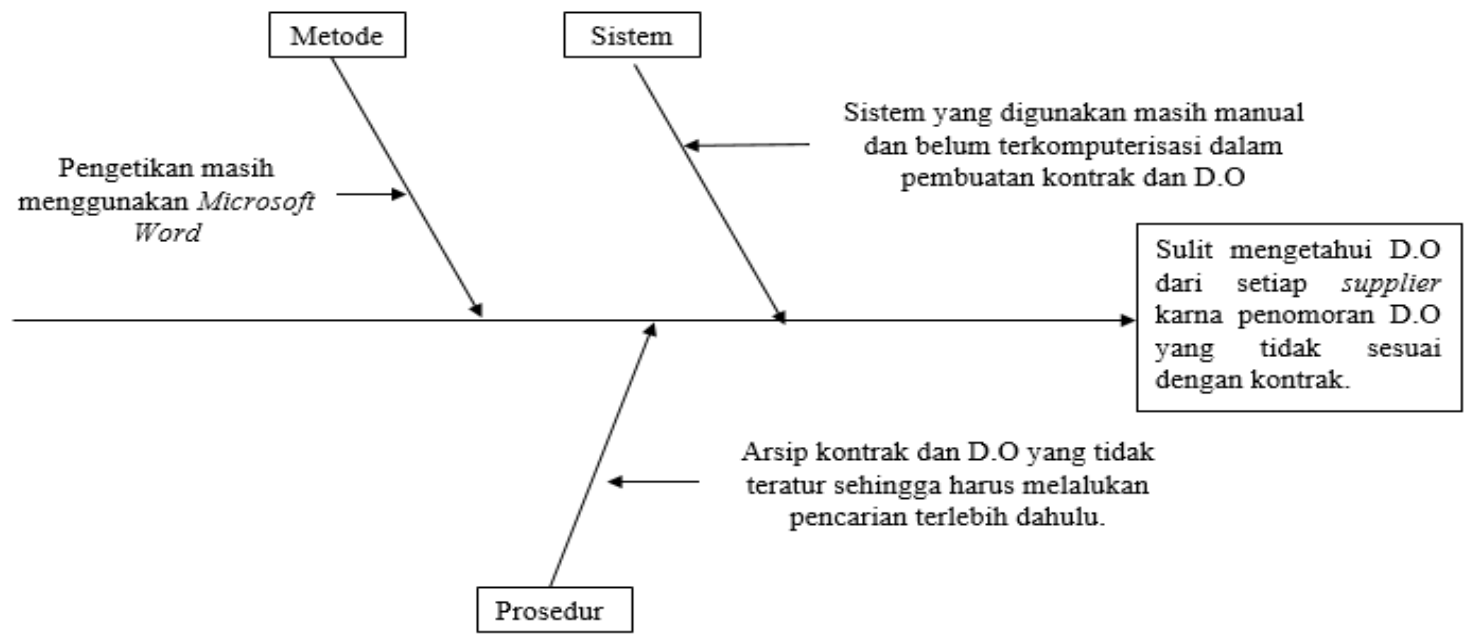

Gambar 1. Fishbone Permasalahan Pertama Pada Perusahaan 


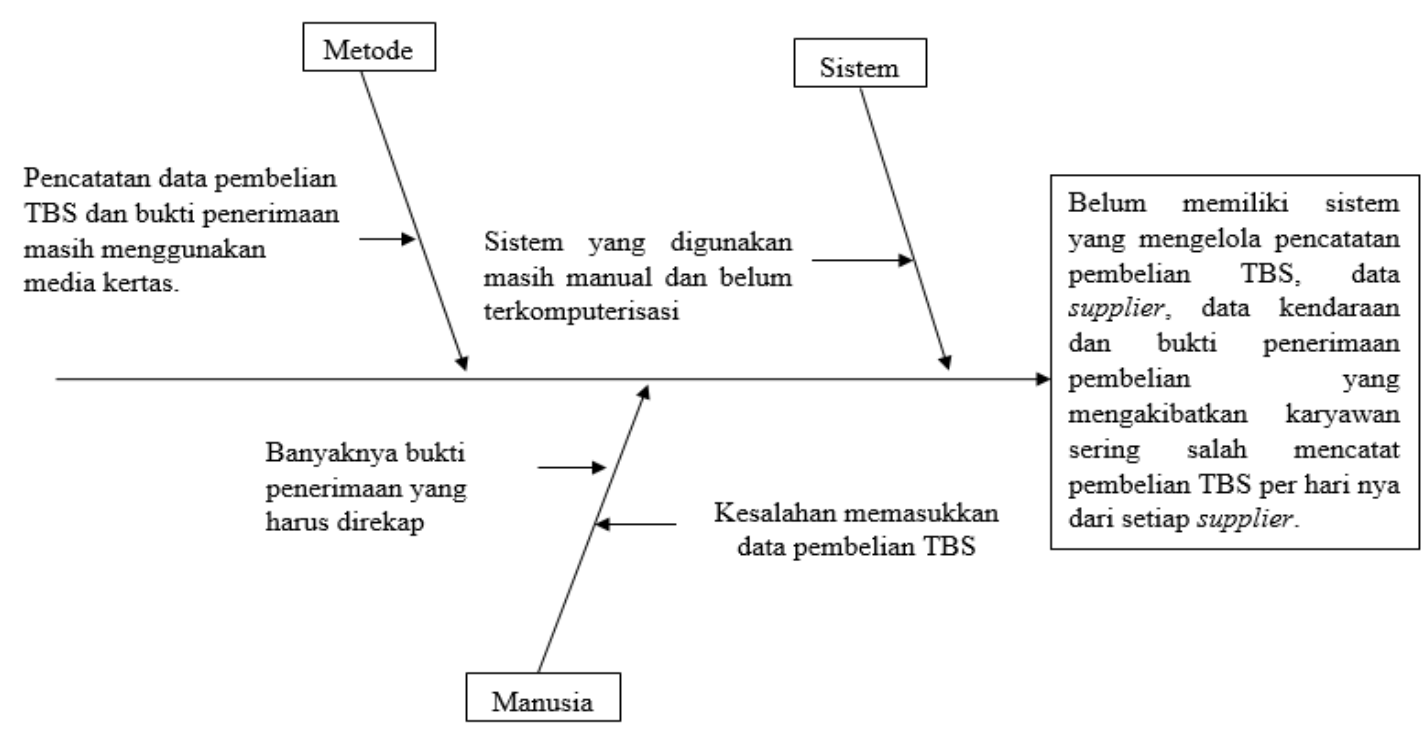

Gambar 2. Fishbone Permasalahan Kedua Pada Perusahaan

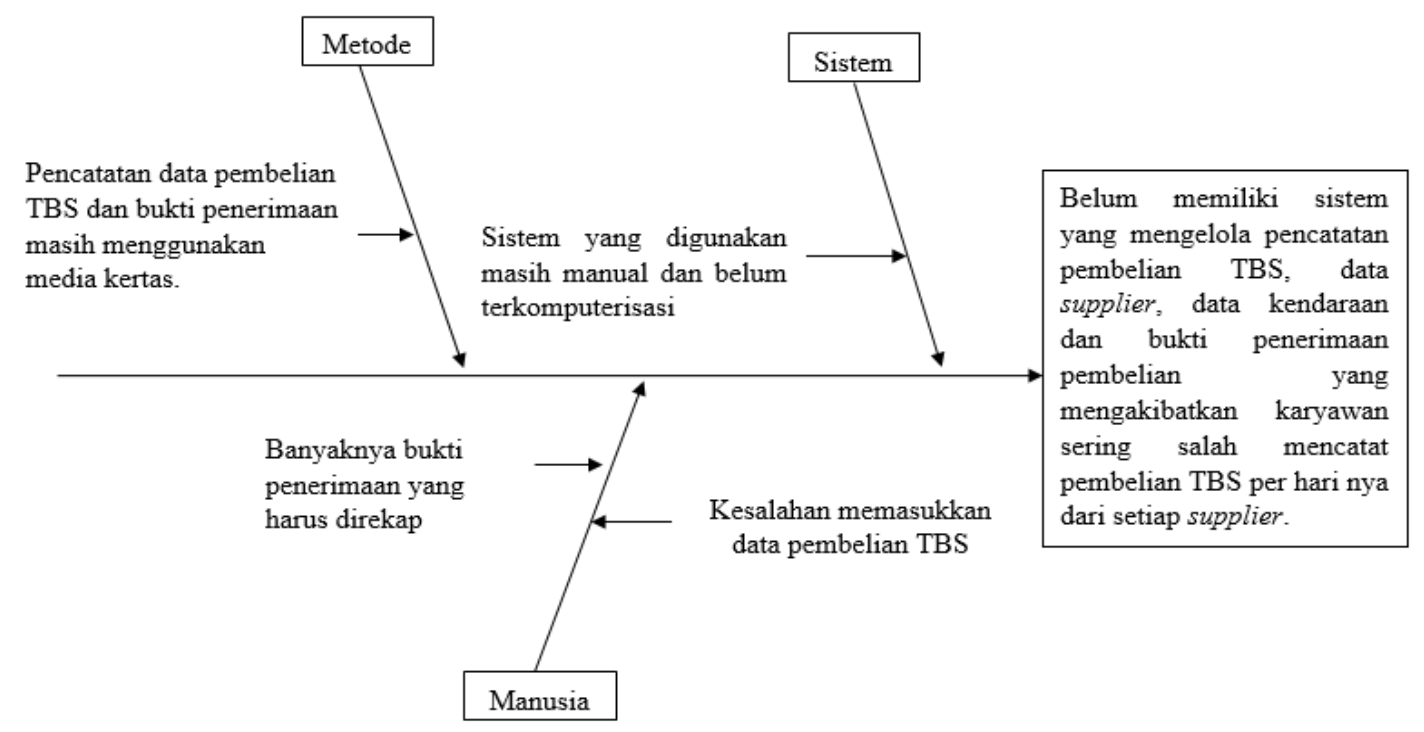

Gambar 3. Fishbone Permasalahan Ketiga Pada Perusahaan

2. Menentukan syarat-syarat informasi

Proses-proses yang dikerjakan pada tahapan ini adalah:

a. Menggambar struktur perusahaan.

b. Menentukan persyaratan yang diperlukan untuk membuat sistem baru seperti sistem baru apa yang digunakan.

c. Menganalisis dokumen masukan dan keluaran.

d. Menggambarkan Data Flow Diagram (DFD) sistem berjalan, sistem usulan dan kamus data. 




Gambar 5. DFD Sistem Berjalan (Kiri) dan DFD Sistem Usulan (Kanan)

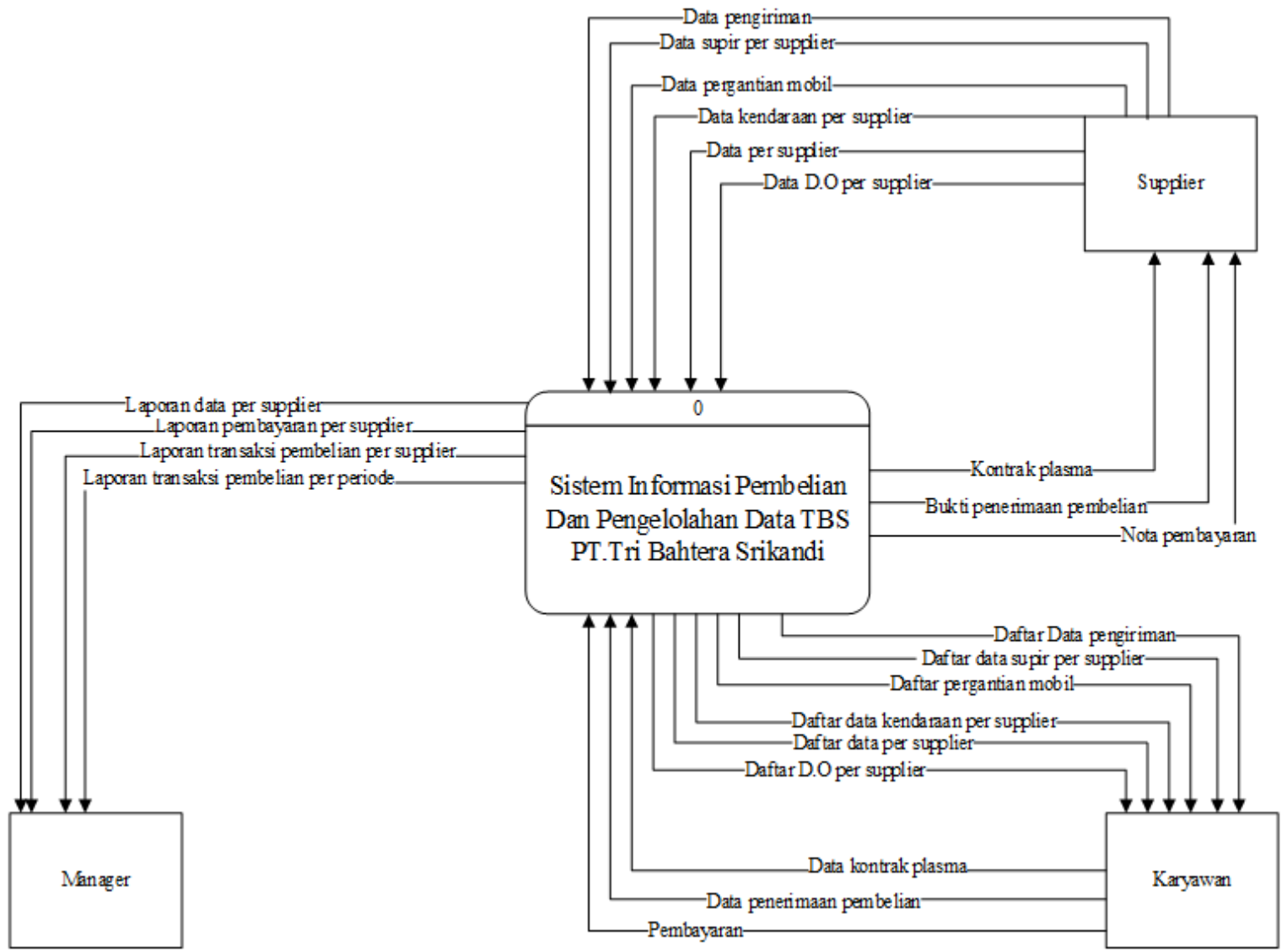

Gambar 5. DFD Sistem Berjalan (Kiri) dan DFD Sistem Usulan (Kanan)

3. Menganalisis kebutuhan sistem

Proses yang dikerjakan pada tahapan ini adalah membuat Data Flow Diagram (DFD) sistem usulan serta mengidentifikasi kebutuhan fungsional dan non fungsional untuk kebutuhan non fungsional akan diidentifikasi menggunakan PIECES. 
Tabel 1. Analisis PIECES

\begin{tabular}{|c|c|c|}
\hline PIECES & Sistem Berjalan & Sistem Usulan \\
\hline Performance & $\begin{array}{l}\text { Sering terjadi penomoran kontrak dan } \\
\text { D.O yang tidak sesuai. } \\
\text { Membutuhkan waktu yang lama dalam } \\
\text { memproses pembelian TBS karena } \\
\text { masih merekap dari media buku. }\end{array}$ & $\begin{array}{l}\text { Sistem baru dapat membuat } \\
\text { penomoran kontrak dan D.O } \\
\text { yang akan sesuai dan berurut. } \\
\text { Sistem baru dapat dengan } \\
\text { mudah memproses pembelian } \\
\text { yang terjadi dalam satu hari. }\end{array}$ \\
\hline Information & $\begin{array}{l}\text { Informasi dalam pembuatan laporan } \\
\text { kurang lengkap dan sering salah dalam } \\
\text { nominal pembayaran karena setiap } \\
\text { data terkadang tercecer, sehingga } \\
\text { pembuatan laporan menjadi rumit. }\end{array}$ & $\begin{array}{l}\text { Dengan menggunakan suatu } \\
\text { rancangan media penyimpanan } \\
\text { dengan sistem yang } \\
\text { terkomputerisasi, diharapkan } \\
\text { akurat, tepat dan lebih cepat. }\end{array}$ \\
\hline Economic & $\begin{array}{l}\text { Penyimpanan masih di media buku, } \\
\text { sehingga membutuhkan biaya untuk } \\
\text { kertas yang dikeluarkan setiap saat } \\
\text { transaksi. }\end{array}$ & $\begin{array}{l}\text { Sistem baru dapat } \\
\text { meminimalkan biaya untuk } \\
\text { kertas, dengan penyimpanan } \\
\text { berbasis komputer. }\end{array}$ \\
\hline Control & $\begin{array}{l}\text { Keamanan data perusahaan tidak } \\
\text { terjamin dan bisa saja kehilangan data } \\
\text { karena masih merekap di media buku } \\
\text { atau kertas. }\end{array}$ & $\begin{array}{l}\text { Keamanan perusahaan dapat } \\
\text { terjaga dengan baik sehingga } \\
\text { bisa diakses oleh pihak yang } \\
\text { berwenang saja. }\end{array}$ \\
\hline Efficient & $\begin{array}{l}\text { Karyawan perlu membongkar arsip } \\
\text { data bukti penerimaan dan D.O satu } \\
\text { persatu pada saat diperlukan sehingga } \\
\text { tidak efisien. }\end{array}$ & $\begin{array}{l}\text { Pencarian data yang diperlukan } \\
\text { dapat terlaksana tepat waktu } \\
\text { karena sudah menggunakan } \\
\text { sistem. }\end{array}$ \\
\hline Service & $\begin{array}{l}\text { Membutuhkan waktu lama dalam } \\
\text { pencarian dan penyajian data. }\end{array}$ & $\begin{array}{l}\text { Dengan menggunakan sistem } \\
\text { yang sudah dirancang, } \\
\text { diharapkan pencarian dan } \\
\text { penyajian data dapat lebih cepat } \\
\text { pelaksanaannya. }\end{array}$ \\
\hline
\end{tabular}

4. Merancang sistem yang direkomendasikan

Proses-proses yang dikerjakan pada tahapan ini adalah:

a. Merancang format laporan yang akan digunakan sebagai keluaran (output) sistem usulan dengan aplikasi Crystal Report.

b. Merancang bentuk antarmuka pemakai (user interface) dari masukan (input) sistem usulan dengan Microsoft Visual Studio 2012.

c. Merancang basis data (database) yang digunakan oleh sistem usulan yang terdiri dari struktur tabel menggunakan Microsoft SQL 2012.

5. Merancang struktur menu sistem usulan dengan menggunakan Microsoft Visual Studio 2012.

\section{PEMBAHASAN DAN HASIL}

Hasil Analisis selanjutnya akan dikembangkan menjadi rancangan menu utama / master, rancangan masukan (input) dan rancangan keluaran (output) seperti berikut :

1. Rancangan Menu

a. Menu Utama dan Menu Master. Dalam tampilan awal ini terdapat empat menu utama yaitu master, transaksi dan laporan. Dalam menu master terdapat lima pilihan menu yang dapat dipilih, yaitu menu data supplier, data D.O per supplier, data kendaraan, data kontrak plasma, data penerimaan pembelian, data supir per supplier, data pengiriman, data pergantian mobil. Dalam data supplier terdapat inti, plasma dan mitra sedangkan pada data D.O per supplier terdapat inti, mitra dan plasma serta pada data kendaraan terdapat juga inti, mitra dan plasma. 

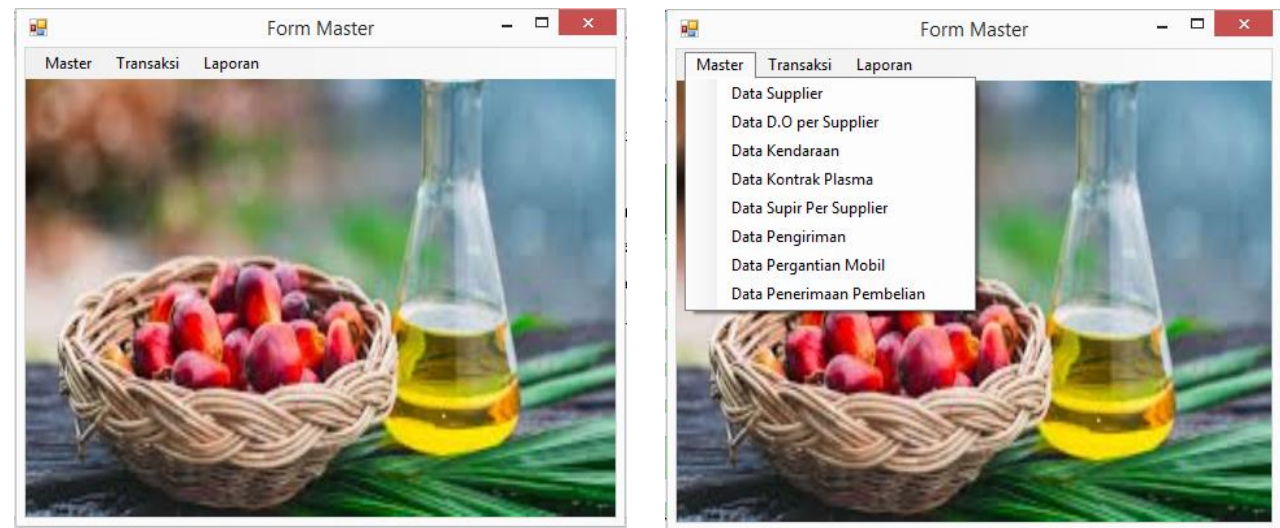

Gambar 6. Menu Utama (Kiri) dan Menu Master (Kanan)

b. Menu Transaksi dan Menu Laporan. Dalam menu transaksi terdapat menu yang dapat dipilih yaitu menu pembayaran. Dalam menu laporan terdapat tujuh pilihan menu yang dapat dipilih yaitu laporan data per supplier, laporan pembayaran per supplier, laporan transaksi pembelian per supplier, laporan transaksi pembelian per periode, daftar data kendaraan, daftar data per supplier, daftar D.O per supplier, daftar data supir per supplier, daftar data pengiriman, daftar data pergantian mobil, nota pembayaran, bukti penerimaan dan kontrak plasma.
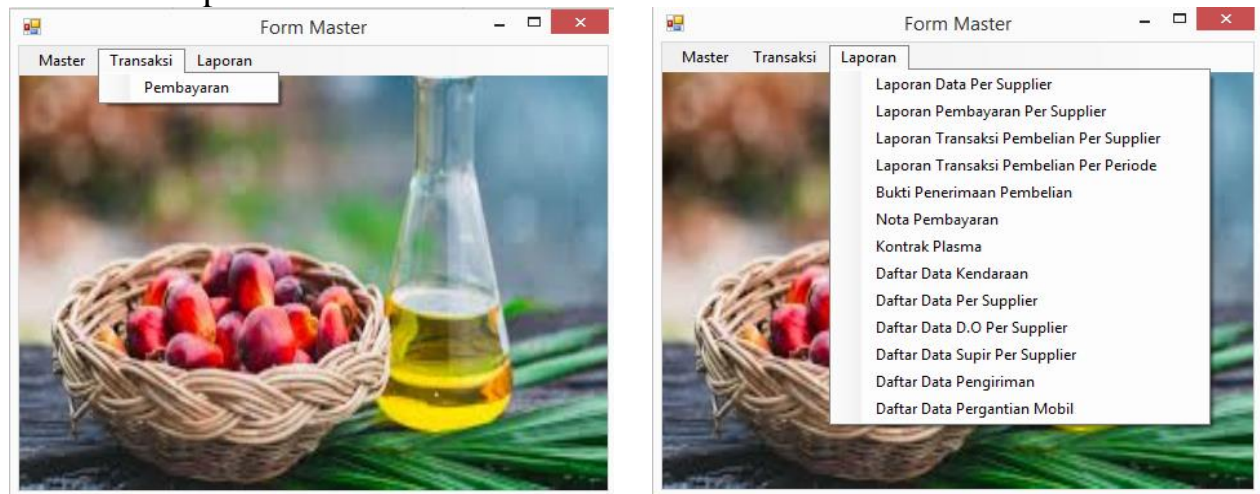

Gambar 7. Menu Transaksi (Kiri) dan Menu Laporan (Kanan)

2. Rancangan Masukan (Input)

a. Form Data Supplier dan Data Kenderaan. Form input data supplier berfungsi untuk pengisian data supplier baru dan pengeditan data supplier. Form input data kendaraan berfungsi untuk pengisian data kendaraan baru dan pengeditan data kendaraan.
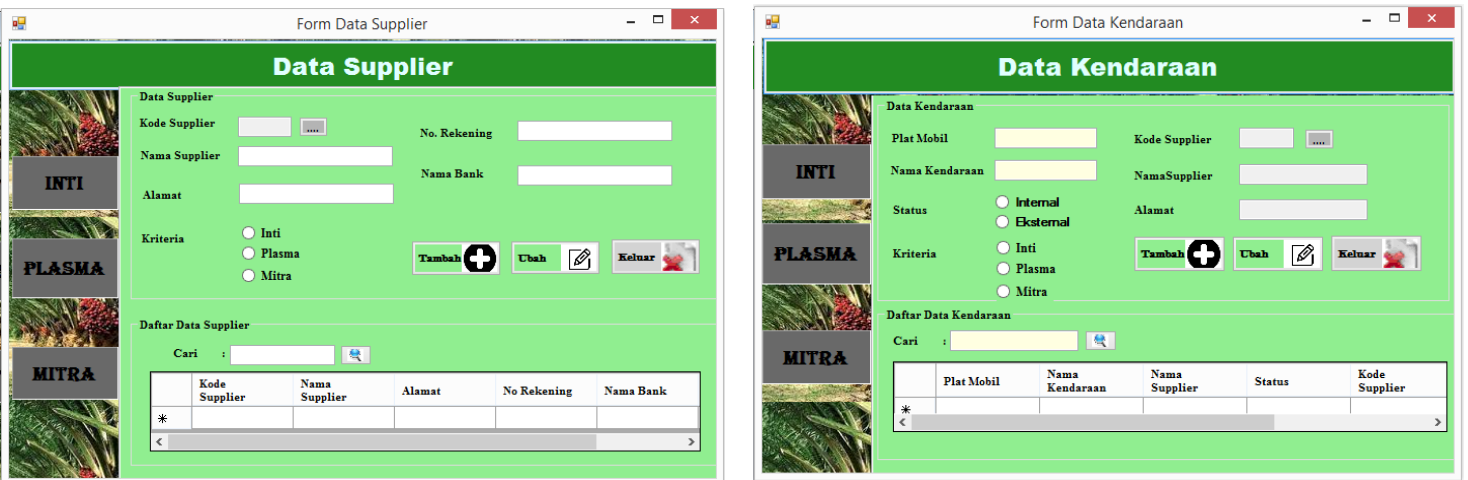

Gambar 8. Form Data Supplier (Kiri) dan Form Data Kendaraan (Kanan) 
b. Form Data Kontrak Plasma dan Data Delivery Order. Form input data kontrak berfungsi untuk pengisian data kontrak baru dan pengeditan data kontrak. Form input data D.O berfungsi untuk pengisian data D.O baru dan pengeditan data D.O.
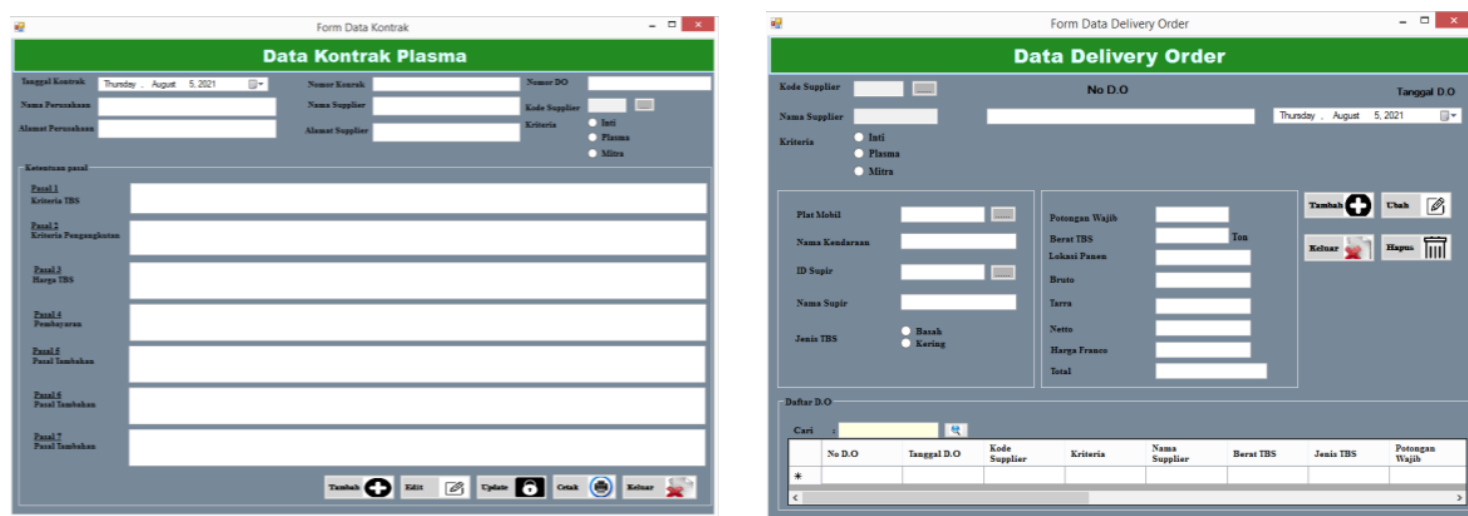

Gambar 9. Form Data Kontrak Plasma (Kiri) dan Form Data Delivery Order (Kanan)

c. Form Data Penerimaan Pembelian dan Pembayaran. Form Input data penerimaan pembelian berfungsi untuk menginput data penerimaan pembelian. Penerimaan ini diterima oleh karyawan timbangan. Form Input data pembayaran berfungsi untuk menginput data pembayaran.
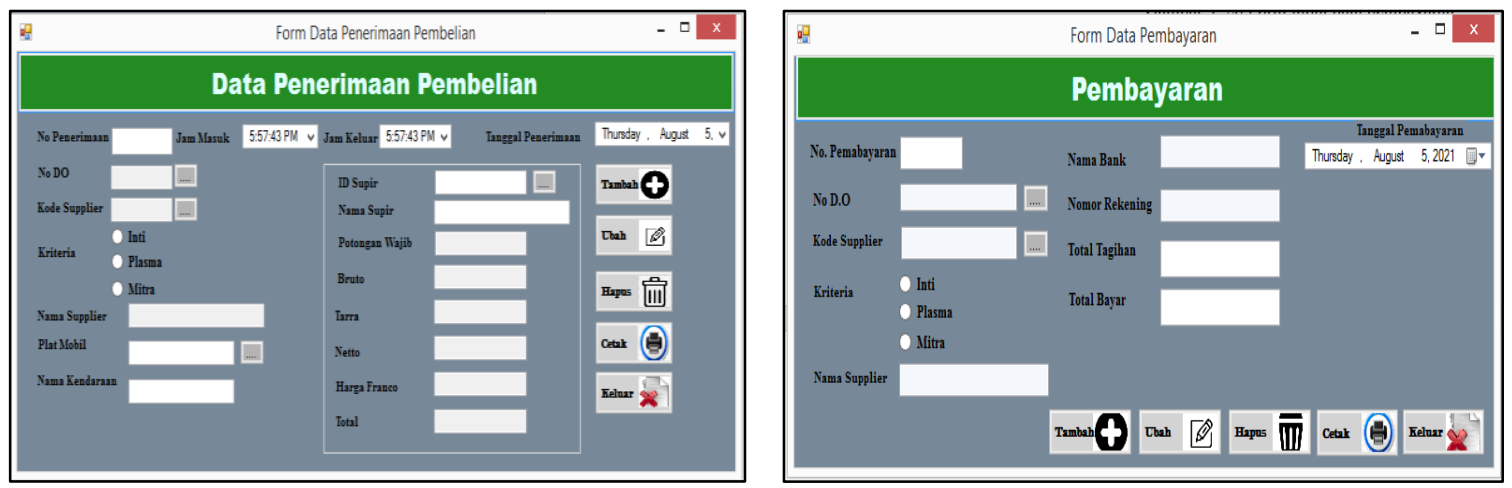

Gambar 10. Form Data Penerimaan Pembelian (Kiri) dan Form Pembayaran (Kanan)

3. Rancangan Keluaran (Output)

a. Laporan Pembayaran. Berikut ini adalah tampilan laporan pembayaran memuat tanggal cetak, waktu cetak, tanggal pembayaran, nomor pembayaran, no D.O, kode supplier, nama supplier, kriteria, total bayar dan total tagihan.



Gambar 11. Laporan Pembayaran

b. Laporan Pembelian Persupplier. Berikut ini adalah tampilan laporan pembelian persupplier memuat tanggal cetak, waktu cetak, tanggal penerimaan, nomor penerimaan, 
kode supplier, nama supplier, plat mobil, kriteria, bruto, tarra, netto, potongan, berat TBS dan total. Pada laporan ini juga terlampir laporan ini dibuat oleh karyawan timbangan serta disetujui oleh manager.

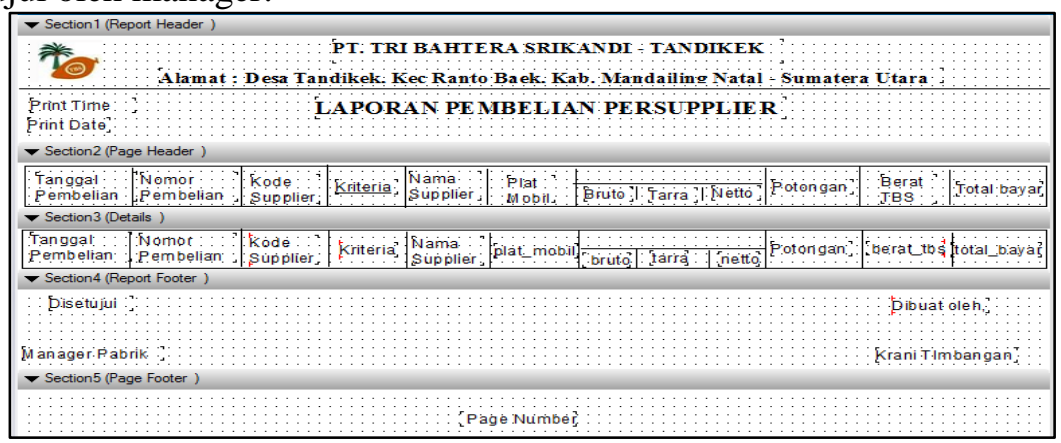

Gambar 12. Laporan Pembelian Persupplier

c. Laporan Penerimaan Pembelian. Berikut ini adalah tampilan bukti penerimaan pembelian memuat nomor penerimaan, tanggal penerimaan pembelian, nomor pembayaran, jam masuk, jam keluar, kode supplier, nama supplier, no D.O, kriteria, plat mobil, bruto, tarra, netto, harga franco dan total bayar. Dalam bukti penerimaan pembelian juga terlampir laporan ini dibuat oleh karyawan timbangan.



Gambar 13. Bukti Penerimaan Pembelian

d. Nota Pembayaran. Berikut ini adalah tampilan nota pembayaran memuat nomor pembayaran, tanggal pembayaran, kode supplier, kriteria, nama supplier, no DO, plat mobil, total tagihan dan total bayar.

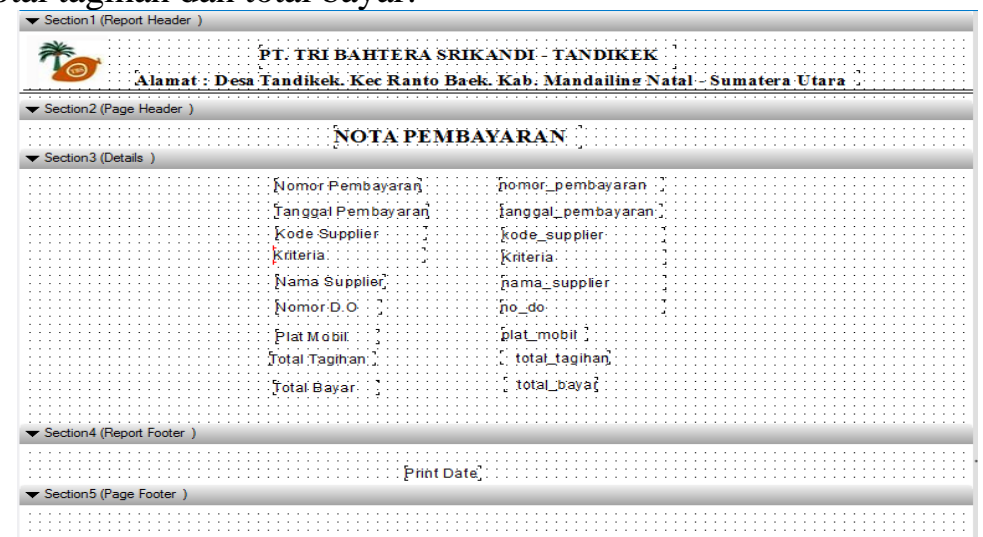

Gambar 14. Nota Pembayaran 
e. Kontrak Plasma. Berikut ini adalah tampilan kontrak plasma memuat tanggal kontrak, nomor kontrak, nama perusahaan, alamat perusahaan, nama supplier, alamat supplier dan ketentuan pasal serta ditandatangani oleh pihak kedua dan pihak pertama.

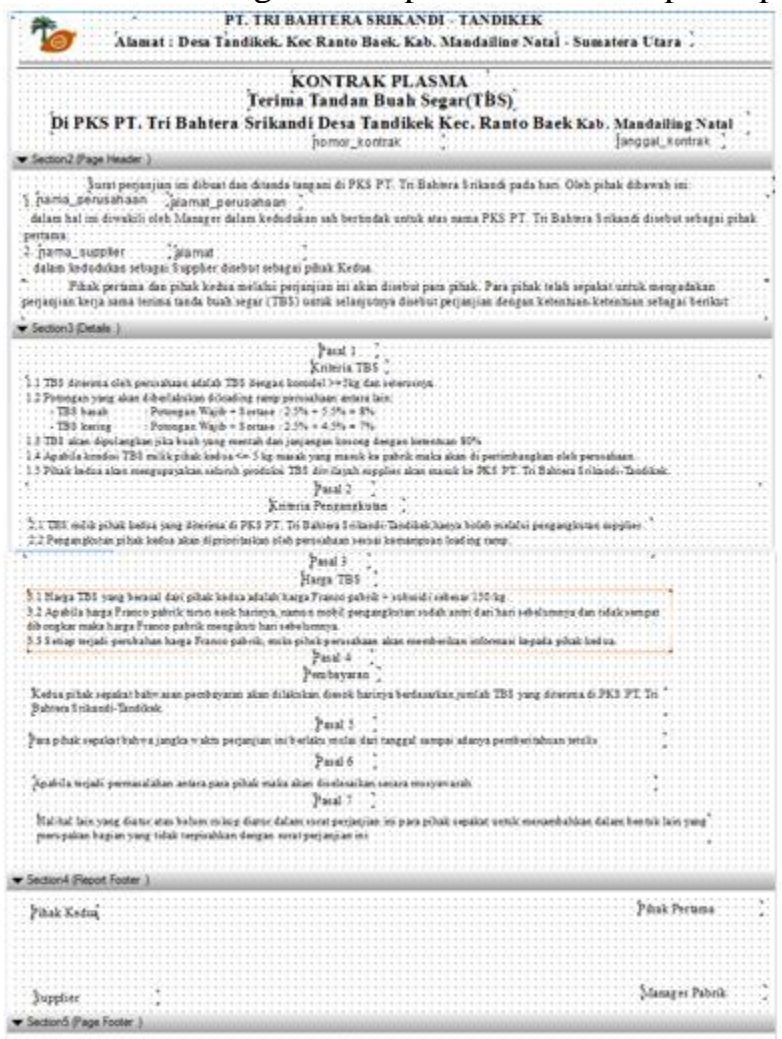

Gambar 15. Kontrak Plasma

\section{KESIMPULAN}

Dengan adanya rancangan sistem usulan pada PT. Tri Bahtera Srikandi ini maka diharapkan dapat menghasilkan rancangan proses, masukan dan keluaran yang dapat mengatasi permasalahan yang dihadapi perusahaan dan mendukung operasional bisnis. Hasil rancangan sistem usulan ini mendukung operasional bisnis seperti dapat mengetahui Delivery Order (DO) dari setiap supplier dengan format penomoran kontrak yang sesuai dengan setiap Delivery Order (DO); dapat membantu masalah pencatatan pembelian TBS; dapat mencatat data supplier, data kendaraan, data supir per supplier, data pengiriman, data pergantian mobil dan bukti penerimaan pembelian; serta dapat menyelesaikan masalah kesulitan dalam melihat pembayaran karena pada sistem usulan ini sudah menampilkan pembayaran lunas dan belum lunas dari setiap supplier.

Saran untuk penelitian ini adalah diharapkan rancangan yang telah dihasilkan dapat dilanjutkan pada tahapan pengembangan sistem sehingga dapat berguna dalam pengolahan data atau transaksi. Dan juga pada masa yang akan datang dapat ditambahkan fitur untuk proses penjualan hasil dari TBS dan penambahan stock pada produksi agar aplikasi tersebut dapat lebih membantu perusahaan.

\section{REFERENSI}

Bakti, A. S. (2020). Rancangan aplikasi sistem informasi produksi buah kelapa Sawit plasma pada PT. Wanasari Nusantara Singingi Hilir. Jurnal Perencanaan, Sains, Teknologi dan Komputer, 371-385.

Harianja, S., Hendri, \& Kisbianty, D. (2018). Perancangan Aplikasi Pembelian Dan Pengelolaan TBS Pada PT. Biccon Agro Makmur Jambi Berbasis Web . Jurnal Ilmiah Media SISFO, $1125-1138$. 
Jr., R. K., Prince, B., \& Cegielski, C. (2014). Introduction to Information System : Supporting and Transforming Business. Wiley.

Kenneth E. Kendall, a. J. (2014). Systems Analysis and Design Ninth Edition. New Jersey: Pearson Education.

Mulyadi. (2018). Sistem Akuntansi. Salemba Empat.

Novendra, R., Syahtriatna, \& Sadar, M. (2019). Pengembangan Sistem Transaksi Penjualan dan Pembelian Pada Peron Sawit. Jurnal ZONAsi, 11-21.

O'Brien, G. M. (2017). Pengantar Sistem Informasi. Jakarta: SALEMBA EMPAT.

Satzinger, J., Jackson, R., \& Burd, S. (2014). Systems Analysis and Design : In A Changing World. Cengage Learning.

Srivastava, A. (2017). Review Paper on Evolution and Need of System Analysis and Design . Asian Journal of Technology and Management Research (AJTMR), 39-47.

Tilley, S., \& Rosenblatt, H. (2017). Systems Analysis and Design, Eleventh Edition. Cengage Learning.

YS, W. L. (2011, Februari 27). Sistem Pengolahan Data. Retrieved September 05, 2020, from https://wawanlaksito.wordpress.com/2011/02/27/22/ 